\title{
SELECTED CHALLENGES AFFECTING THE RETROACTIVE TRANSFER PRICING ADJUSTMENTS OF IMPORTED GOODS IN SOUTH AFRICA*
}

\author{
Howard Chitimira \\ LLB LLM LLD \\ Research Professor and Professor of Securities \\ \& Financial Markets Law, Faculty of Law \\ North-West University \\ Oratile Maselwa \\ LLB LLM \\ Candidate Attorney \\ Shepstone and Wylie Attorneys
}

\section{SUMMARY}

The article analyses selected challenges associated with retroactive transfer pricing adjustments of imported goods under the Customs and Excise Act 91 of 1964 (Customs and Excise Act). This is done in order to examine the regulatory challenges affecting retroactive transfer pricing adjustments and customs valuation processes of imported goods under the Customs and Excise Act. Thus, the enforcement of retroactive transfer pricing adjustments of imported goods for Multinational Enterprises (MNEs) is scrutinised in terms of the Customs and Excise Act. To this end, the article provides an overview analysis of selected regulatory and related challenges affecting retroactive transfer pricing adjustments and actual valuation processes of imported goods within different MNEs in South Africa. Accordingly, the article explores selected challenges in order to recommend possible remedies and measures that could be employed by policy makers to enhance the regulatory and enforcement framework under the Customs and Excise Act.

Transfer pricing generally occurs when the demarcated price at which certain goods or services are provided by Multinational Enterprises (MNEs) is transferred to other companies or enterprises that are subsidiaries of the same MNEs. Put differently, transfer pricing refers to the sharing of transaction prices between related MNEs or bigger companies and their 
controlled subsidiary companies. This normally occurs during the buying and selling of goods or services within related MNEs and/or their subsidiaries. ${ }^{1}$ On the other hand, retroactive transfer pricing adjustments of imported goods are effected by MNEs and/or their subsidiary companies at the end of a financial year in order to achieve a certain target and/or gross margin in relation to their core business activities. Thus, retroactive transfer pricing adjustments refer to the adjustments made to the cost price of the goods or services that are imported by MNEs throughout the year to ensure that they reflect the true price in their financial-year-end documents. The adjustments are usually made when the price of the imported goods or services were either too low or too high at the time of the initial transactions to ensure that they correctly reflect the actual prices. Retroactive transfer adjustments of imported goods and services are effected in accordance with the arm's length principle (ALP), which, inter alia, enables transfer prices to be periodically set, monitored and carefully adjusted to ensure that their correctness and profitability are protected. The ALP requires that the financial results of MNEs be reviewed and where possible, a transfer pricing adjustment be made either as a debit and/or credit note to enable the MNEs in question to satisfy the targeted operating profit margin at the end of a financial year. ${ }^{2}$ Notably, all transfer pricing adjustments made at the end of a financial year constitute retroactive adjustments that must be effected by the relevant parties at arm's length. ${ }^{3}$ The ALP was first used in the early 1900s in some treaties of developed countries such as France, the United Kingdom (UK) and the United States of America (USA). ${ }^{4}$ The ALP was first adopted in article 3 of the League of Nations Draft Convention on the Allocation of Profits and Property of International Enterprises of 1933..$^{5}$ Thereafter, the ALP was adopted in the Organisation for Economic Co-operation and Development (OECD) Draft Tax Convention of 1963 and was subsequently employed in all tax-related instruments of the OECD, such as in the Model

* This article was influenced in part by Maselwa's Master of Laws (LLM) dissertation, The Regulation of Retroactive Transfer Pricing Adjustments and Valuation of Imported Goods Under the Customs and Excise Act 91 of 1964 (unpublished LLM dissertation, North-West University) 2018 64-78.

1 Ngundi Transfer Pricing Management Strategies by Multinational Enterprises Within the Main Investment Segment of the Nairobi Securities Exchange (unpublished MBA dissertation, University of Nairobi) 2012 1-41; Allan The OECD Transfer Pricing Guidelines: An Analysis of Their Application in the South Africa Legal Regime (unpublished LLM dissertation, University of Cape Town) 2007 1-83; Perčević and Hladika "Application of Transfer Pricing Methods in Related Companies in Croatia" 2017 Economic Research 611 613-626; Benari "Tricky Tax: Two Tax Avoidance Schemes Explained" (10 June 2009) http://www.financialtransparency.org/wp-content/uploads/2015/04/Tricky Tax GBenari.pdf (accessed 2020-11-26) 1-15, who argues that transfer pricing is the setting of prices for internal transactions between two subsidiaries of the same company; Cristea and Nguyen "Transfer Pricing by Multinational Firms: New Evidence From Foreign Firm Ownerships" 2016 American Economic Journal: Economic Policy 170 171-202; Merville and Petty "Transfer Pricing for the Multinational Firm" 1978 The Accounting Review 935 936-951.

2 Baistrocchi "The Transfer Pricing Problem: A Global Proposal for Simplification" 2006 The Tax Lawyer 941 959-979.

3 Ibid.

4 World Customs Organisation "Guide to Customs Valuation and Transfer Pricing" 2018 WCO Guide 4 6-75.

5 World Customs Organisation 2018 WCO Guide 16-18. 
Tax Conventions as well as the United Nations (UN) tax treaties. ${ }^{6}$ The ALP entails that the prices, profit margins, quantities of goods and other conditions of any transactions between related parties should be similar to those that would have prevailed between two unrelated and independent parties in similar transactions under similar conditions. ${ }^{7}$ The ALP obliges all related parties to price their goods and related transactions objectively, as if they were wholly independent of each other. This is probably aimed at curbing aggressive tax avoidance and tax evasion so as to ensure that the taxable profits of MNEs are not illegally syphoned out of their jurisdictions. ${ }^{8}$ Moreover, it is submitted that the ALP is employed to ensure that the tax base reported by MNEs in their countries correctly reflects the relevant transactions in respect thereof, and so to curb double taxation disputes that could ensue between affected countries in relation to the determination and application of the ALP on remuneration and other related cross-border transactions. ${ }^{9}$ Nevertheless, the terms "retroactive transfer pricing" and "transfer pricing" are not expressly defined in the Customs and Excise Act, ${ }^{10}$ the Customs Duty Act ${ }^{11}$ and the Customs Control Act ${ }^{12}$ in South Africa.

Illegal transfer pricing and illegal retroactive transfer pricing adjustments occur when MNEs manipulate the prices of goods sold within such MNEs and/or their subsidiary companies inter alia to evade customs duties on imported goods in a bid to gain illegal profits. ${ }^{13}$ In South Africa, the South African Revenue Service (SARS) works hand in hand with the Customs Valuation Department to oversee transfer pricing, retroactive transfer pricing and the customs valuation processes of imported goods. SARS is empowered to issue compliance notices regarding retroactive transfer pricing adjustments and to police taxpayers' compliance with customs rules in South Africa. ${ }^{14}$ In this regard, it is important to note that the customs value of imported goods is determined by using the price payable for such goods when they are sold for export purposes in South Africa. This is done in accordance with the price determined by the transfer pricing policy for related-party transactions in South Africa. ${ }^{15}$ Thus, the transfer price is annually adjusted upwards or downwards to bring the profit margins within a range determined by the transfer pricing policy at arm's length. Transfer pricing adjustments may have a negative impact on the customs value of

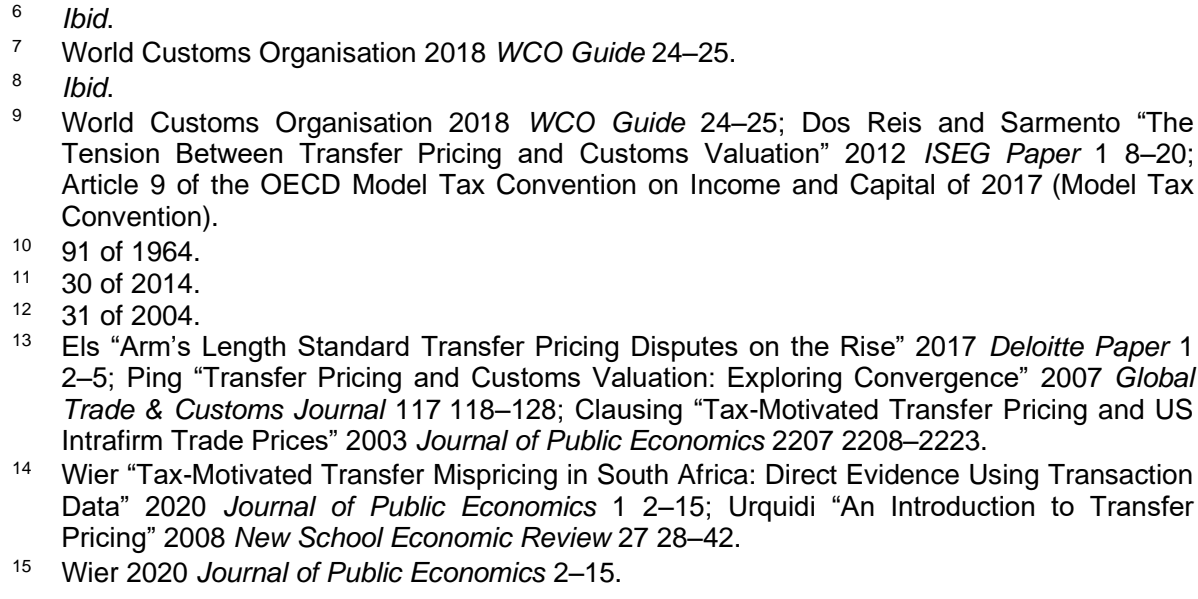

13 Els "Arm's Length Standard Transfer Pricing Disputes on the Rise" 2017 Deloitte Paper 1 2-5; Ping "Transfer Pricing and Customs Valuation: Exploring Convergence" 2007 Global Trade \& Customs Journal 117 118-128; Clausing "Tax-Motivated Transfer Pricing and US Intrafirm Trade Prices" 2003 Journal of Public Economics 2207 2208-2223.

14 Wier "Tax-Motivated Transfer Mispricing in South Africa: Direct Evidence Using Transaction Data" 2020 Journal of Public Economics 12-15; Urquidi "An Introduction to Transfer Pricing" 2008 New School Economic Review 27 28-42.

15 Wier 2020 Journal of Public Economics 2-15. 
imported goods, especially when the payable price of such goods was declared as the customs value to SARS, which requires additional retroactive transfer pricing adjustments for customs purposes in South Africa. ${ }^{16}$ The Customs Valuation Department and the Transfer Pricing Department of SARS are reportedly collaborating relatively well to increase information sharing and conduct joint audits in order to curb double taxation problems in South Africa. ${ }^{17}$ This has enabled SARS to detect some year-end non-compliance cases of retroactive transfer pricing adjustments between MNEs and related parties.

South Africa has tightened its control measures for customs valuation and transfer pricing in relation to cross border transactions within MNEs and their subsidiary companies by increasing the number of audits conducted. ${ }^{18}$ Since 2012, this is evident in increased SARS audits on retroactive transfer pricing adjustments and related transactions recorded in South Africa. ${ }^{19}$ These audits are conducted by SARS in an attempt to curb possible manipulation and abuse of retroactive transfer pricing adjustments and customs valuations of imported goods in South Africa. ${ }^{20}$ Accordingly, any improper transactions where MNEs do not perform their retroactive transfer pricing adjustments well are detected and penalised by SARS.

Retroactive transfer pricing adjustments are still prone to manipulation by MNEs in South Africa. ${ }^{21}$ This could be indicative of the gaps and flaws in the current customs and valuation regulatory framework on imported goods in South Africa. ${ }^{22}$ For instance, the Customs and Excise Act, ${ }^{23}$ the Customs Duty Act $^{24}$ and the Customs Control Act ${ }^{25}$ do not have provisions that adequately provide for retroactive transfer pricing adjustments. As a result, SARS has to date struggled to detect and combat the aggressive tax avoidance and tax evasion activities perpetrated by MNEs and/or their subsidiary companies through illegal retroactive transfer pricing adjustments and incorrect customs valuation processes. This is exacerbated by the fact

16 Ibid.

17 Ibid.

18 Els 2017 Deloitte Paper 2-5; Wier 2020 Journal of Public Economics 2-15; Tuominen The Link Between Transfer Pricing and the EU Customs Valuation Law: Is There Any and How Could It Be Strengthened? (masters dissertation, Lund University) 2018 7-9.

19 Wier 2020 Journal of Public Economics 2-15; Zuvich, Abad and Zaharatos "Enhancing Compliance Through Customs and Tax Coordination" 2010 Tax Executive 41-46; Marsilla "Customs Valuation and Transfer Pricing" 2008 ERA Forum 399-412.

20 Wier 2020 Journal of Public Economics 2-15; Allan The OECD Transfer Pricing Guidelines 4-83; Neubig and Wunsch-Vincent "A Missing Link in the Analysis of Global Value Chains: Cross-Border Flows of Intangible Assets, Taxation and Related Measurement Implications" 2017 Economic Research Working Paper No. 37 3-45.

21 Markham Advance Pricing Agreements: Past, Present and Future (2012) 33-400; Florence "Transfer Pricing: Challenges and Solutions Within the Asean Regime" 2016 Indonesian Journal of International Law 60 61-80 and Beebeejaun "The Efficiency of Transfer Pricing Rules as a Corrective Mechanism of Income Tax Avoidance” 2018 Journal of Civil \& Legal Sciences $12-8$.

22 Wier 2020 Journal of Public Economics 3-15; see further Solomon "Multinational Corporations and the Emerging World Order" 1976 Case Western Reserve Journal of International Law 329 330-428.

23 Ss 65-67 and 71-74A of the Customs and Excise Act.

24 Ss 127-140 of the Customs Duty Act.

25 Ss 411-429 of the Customs Control Act. 
that the Customs and Excise Act, the Customs Control Act and the Customs Duty Act $^{26}$ do not provide a clear valuation method for use on retroactive transfer pricing adjustments of imported goods in South Africa. Additionally, these Acts do not have specific provisions that deal with the administrative burden that comes with the processing of numerous vouchers of correction during retroactive transfer pricing adjustments to amend incorrect customs valuation processes and prices of imported goods. ${ }^{27}$ It is also very difficult for SARS to obtain and evaluate the transfer pricing policies of MNEs timeously during their annual retroactive transfer pricing adjustments. ${ }^{28}$ This difficulty is worsened by the fact that the current customs and valuation laws do not impose a statutory obligation on MNEs to have their own transfer pricing policies, ${ }^{29}$ which must be shared with SARS, especially during retroactive transfer pricing adjustments. Without access to the transfer policy of the relevant MNEs, it is almost impossible for SARS to determine the actual transaction value of the goods and services sold within the MNEs. ${ }^{30}$ Moreover, the current customs and valuation regulatory framework does not specify what must be included in the transfer pricing policies of MNEs and this gap could give rise to manipulative retroactive transfer pricing adjustments of imported goods in South Africa. The task of compiling transfer pricing documents is onerous and cumbersome for MNEs since there is no statutory guidance on the format and contents of a transfer pricing policy. ${ }^{31}$ Neither SARS nor the relevant customs and valuation laws provides guidance on the contents of a transfer pricing policy, which makes it very difficult for MNEs to compile the relevant information on their retroactive transfer pricing adjustments of imported goods. ${ }^{32}$ The limited

26 Ss $65-67$ and 71-74A of the Customs and Excise Act; ss 112-140 of the Customs Duty Act and ss 411-429 of the Customs Control Act; see related discussion by Fyfe Understanding and Managing Risks at the Intersection of Transfer Pricing and Customs Valuation Rules (LLM dissertation, University of Pretoria) 2016 17-108; Fritz An Appraisal of Selected TaxEnforcement Powers of the South African Revenue Services in the South African Constitutional Context (unpublished LLD thesis, University of Pretoria) 2017 57-303.

27 See related discussion by Vinti "The Scope of the Powers of the Minister of Finance in terms of Section 48(1)(b) of the Customs and Excise Act 91 of 1964: An Appraisal of Recent Developments in Case Law" 2018 Potchefstroom Electronic Law Journal $12-22$; Subban "Draft Customs Control Bill and Draft Customs Duty Bill Released for Public Comment" 2009 Tax Insight 4.

28 Ratombo and Blumenthal "The Challenges Faced by Developing Countries Regarding Transfer Pricing" 2017 Southern African Accounting Association Biennial International Conference Proceedings 749 751-764.

29 A transfer pricing policy is an intercompany policy that sets out how transactions of goods sold within MNEs are priced. See further Fyfe Transfer Pricing and Customs Valuation Rules 35-36.

30 Allan The OECD Transfer Pricing Guidelines 4-83; Neubig and Wunsch-Vincent 2017 Economic Research Working Paper No. 37 3-45; Eden "Taxes, Transfer Pricing, and The Multinational Enterprise" in Rugman (ed) The Oxford Handbook of International Business 2ed (2009) 591-617.

31 See Meditor Capital Management Ltd v Feighan (HMIT) (2004) SPC (SCD) 409 par 273, in which the taxpayer did not provide the revenue authority with a transfer pricing policy and argued that information requested by the revenue authority was irrelevant to determine the tax liability. The court ruled in favour of the revenue authority and held that information that might be relevant to determine tax liability must be provided. See further Cooper, Fox, Loeprick and Mohindra Transfer Pricing and Developing Economies: A Handbook for Policy Makers and Practitioners (2016) 2-129.

32 Vinti 2018 Potchefstroom Electronic Law Journal 2-22; also see Friedhoff and Schippers "ECJ Judgment in Hamamatsu Case: An Abrupt End to Interaction Between Transfer 
resources available to SARS is another negative challenge that is impeding the proper enforcement of legitimate retroactive transfer pricing adjustments to combat possible manipulation by MNEs in South Africa. ${ }^{33}$

Owing to poor regulatory oversight, some MNEs are still able to manipulate their retroactive transfer adjustments of imported goods in South Africa through under-invoicing ${ }^{34}$ of their transactions in order to pay lower import duties and less value added tax (VAT). ${ }^{35}$ Downward retroactive transfer adjustments occur when the MNEs adjust the values of the goods bought and imported within such MNEs to be lower than what they would ordinarily be if the same goods were bought and sold between unrelated independent parties. ${ }^{36}$ Under-invoicing occurs when the selling company within the MNE charges the related buying company lower prices. ${ }^{37}$ Both under-invoicing and downward retroactive transfer adjustments are actions that can only occur between related parties, usually MNEs and their subsidiary companies. Consequently, retroactive transfer pricing adjustments pose a serious risk of under-invoicing and downward adjustments by unscrupulous MNEs, which resort to such unlawful activities to avoid paying high duties on their imported goods in South Africa. ${ }^{38}$

Given this background, the article analyses selected regulatory challenges associated with retroactive transfer pricing adjustments on imported goods under the Customs and Excise Act. This is done in order to examine the regulatory challenges affecting the retroactive transfer pricing adjustments and customs valuation processes of imported goods under the Customs and Excise Act. Thus, the enforcement of retroactive transfer pricing adjustments of imported goods for MNEs is scrutinised in terms of the Customs and Excise Act. To this end, the article provides an overview analysis of selected regulatory and related challenges affecting the retroactive transfer pricing adjustments and the actual valuation processes of imported goods within

Pricing and Customs Valuation?" 2019 EC Tax Review 32 33-42 and Cooper et al Transfer Pricing and Developing Economies 2-129; Ping 2007 Global Trade \& Customs Journal 118-128.

33 Harmse and Van der Zwan "Alternatives for the Treatment of Transfer Pricing Adjustments in South Africa" 2016 De Jure 288 290-306.

34 Cooper et al Transfer Pricing and Developing Economies 2-129; Ping 2007 Global Trade \& Customs Journal 118-128; Ratombo and Blumenthal 2017 Southern African Accounting Association Biennial International Conference Proceedings 751-764.

35 Harmse and Van der Zwan 2016 De Jure 290-306; Eden in Rugman Oxford Handbook of International Business 591-617; Ping 2007 Global Trade \& Customs Journal 118-128; Musselli and Bürgi Curbing Illicit Financial Flows in Commodity Trading: Tax Transparency (CDE Working Papers 4) (2018) 17-58.

36 Allan The OECD Transfer Pricing Guidelines 4-83; also see Atci "Transfer Pricing and Customs Valuation Overlap: Is It Possible to Bridge Two Worlds?" 2020 Gazi Journal of Economics and Business 71 72-84; Bakker and Obuoforibo Transfer Pricing and Customs Valuation (2009) 41-450.

37 Atci 2020 Gazi Journal of Economics and Business 73. See related discussion by Geremew Assessment of Under Invoicing Valuation System: The Case of Profit Tax and Accounting Practice (unpublished MBA dissertation, St. Mary's University) 2017 18-33; Truel A Short Guide to Customs Risk (2010) 42-100.

38 Truel Guide to Customs Risk 42-100; Geremew Under Invoicing Valuation System 18-33; Michaeletos "More Holistic Planning Around Custom Valuation and Transfer Pricing 2013 South African Institute of Tax Professionals; Fyfe Transfer Pricing and Customs Valuation Rules 35-36. 
different MNEs in South Africa. The selected challenges are explored in order to recommend possible remedies to such challenges as well as possible measures that could be employed by policy makers to enhance the regulatory and enforcement framework under the Customs and Excise Act.

\section{CHALLENGES AFFECTING RETROACTIVE TRANSFER PRICING ADJUSTMENTS OF IMPORTED GOODS IN SOUTH AFRICA}

\section{Difficulties with requirement that MNEs pass a voucher of correction}

A voucher of correction is a document that is mostly used in the South African shipping industry to amend any details that need to be changed in the bill of entry that has already been filed for a particular shipment with the customs department. Therefore, a voucher of correction is used by the South African customs department to update or amend details in a declaration or bill of entry that has already been passed and submitted to SARS in accordance with the Customs and Excise Act. ${ }^{39} \mathrm{~A}$ voucher of correction is required when a bill of entry does not comply with the relevant requirements as set out in the Customs and Excise Act. ${ }^{40} \mathrm{~A}$ clearing agent normally processes a voucher of correction on behalf of an importer and/or exporter, especially where there are amendments that need to be effected to the original bill of entry. ${ }^{41}$ Retroactive transfer pricing adjustments must be effected by MNEs on each import transaction. As a result, an MNE in question is obliged to comply with this requirement for each import declaration in order to adjust either upward or downward the value of goods previously declared on the bill of entry so as to reflect the correct value..$^{42}$ Retroactive transfer pricing adjustments of the value of imported goods by MNEs usually affect the import duties that were paid at the time of importation; it is very difficult for SARS to levy import duties that are proportional to the original transaction value of the affected goods. ${ }^{43}$ An upward retroactive transfer pricing adjustment of the value of imported

39 S 40(3) of the Customs and Excise Act; see further Harmse and Van der Zwan 2016 De Jure 290-306; Fyfe Transfer Pricing and Customs Valuation Rules 31-36.

40 S 39 read with ss 39A and 39D of the Customs and Excise Act; see Commissioner for the South African Revenue Service v Terraplas South Africa (Pty) Ltd (375/2013) [2014] ZASCA 69 par 4-24.

41 Ss 98, 99, 99A and 100 of the Customs and Excise Act; see further Commissioner for Customs and Excise v Container Logistics (Pty) Ltd, Commissioner for Customs and Excise $v$ Rennies Group Limited t/a Renfreight (196/96, 198/96) [1999] ZASCA 35 par 9-22.

42 Lux, Cannistra and Cuadros "The Customs Treatment of Royalties and License Fees With Regard to Imported Goods" 2012 Global Trade and Customs Journal 120 122-142; Ainsworth "IT-Advanced Pricing Agreements: Harmonizing Inconsistent Transfer Pricing Rules in Income Tax-Customs VAT" 200734 Rutgers Computer \& Tech. LJ 1 4-167.

43 Ss 39, 39A, 39D, 44 and 44A of the Customs and Excise Act. See further Trend Finance (Pty) Ltd v Commissioner for the South African Revenue Service [2005] 4 All SA 657 (C) par 70-100; CSARS v Van der Merwe NO (598/2015) [2016] ZASCA 138 par 16-28; International Business Machines SA (Pty) Ltd $v$ Commissioner for Customs and Excise 1985 (4) SA 852 (A); Gupta "The Arbitrary Rejection of the Declared Value by the Customs Administration" 2020 Global Trade and Customs Journal 42 44-49. 
goods entails that the customs value is higher than what it was at the time of importation. Accordingly, there will be outstanding import and/or customs duties that must be settled by the affected MNE. ${ }^{44}$ This essentially entails that affected MNEs have to comply with the onerous requirements of compiling and sending a voucher of correction to SARS in respect of all retroactive transfer pricing adjustments of imported goods in South Africa.

On the other hand, a downward retroactive transfer pricing adjustment entails that the customs value of the imported goods should be adjusted lower than what it was at the time of importation. ${ }^{45}$ This means that higher duties were paid by the MNE at the time of importation. ${ }^{46}$ In this regard, an affected MNE must comply with the onerous requirements of compiling and sending a voucher of correction to SARS to get a refund in respect of the overpaid duties. ${ }^{47}$ In other words, before SARS can collect the duties that were underpaid at the time of importation through an upward retroactive transfer pricing adjustment, or before SARS can refund MNEs in the case of a downward retroactive transfer pricing adjustment, ${ }^{48}$ a voucher of correction for all affected entries must be submitted to SARS by the relevant MNEs for processing and amendment of the customs value of every bill of entry that was subjected to the adjustments. This remains an onerous and challenging task for MNEs since the required vouchers of correction might involve thousands of bills of entry, each of which require a separate voucher of correction. Furthermore, it causes an administrative burden for SARS to process and approve numerous vouchers of correction for several bills of entry in respect of each retroactive transfer pricing adjustment performed by MNEs in South Africa. Likewise, it is costly for MNEs to enlist the services of clearing agents to process the numerous vouchers of correction that are required in respect of retroactive transfer pricing adjustments in South Africa.

Notably, a previous bill of entry for imported goods does not suffice as a valid entry under the provisions of the Customs and Excise Act, particularly after retroactive transfer pricing adjustments were effected by MNEs to correct and provide a true customs value for relevant imported goods. ${ }^{49}$ As indicated above, MNEs must compile and submit a voucher of correction to SARS after retroactive transfer pricing adjustments are effected to substitute an original bill of entry with a new bill of entry that reflects the new customs value for the affected imported goods. The term "customs duty" means any duty that could be levied on the importer and/or MNEs under Part 1 of Schedule 1 or Schedule 2 of the Customs and Excise Act, on goods imported into South Africa. ${ }^{50}$ Furthermore, for the purposes of the Southern

44 Marsilla "Towards Customs Valuation Compliance Through Corporate Income Tax" 2011 World Customs Journal 73 74-84; Bakker and Obuoforibo Transfer Pricing 41-450; Dos Reis and Sarmento 2012 ISEG Paper 8-26.

45 Ping 2007 Global Trade \& Customs Journal 118-128.

46 Marsilla 2011 World Customs Journal 74-84.

47 Bakker and Obuoforibo Transfer Pricing 41-450; Dos Reis and Sarmento 2012 ISEG Paper 8-26.

48 Wier 2020 Journal of Public Economics 3-15; Bakker and Obuoforibo Transfer Pricing 41-450; Dos Reis and Sarmento 2012 ISEG Paper 8-26.

49 Wier 2020 Journal of Public Economics 3-15; ss39, 39A, 39D, 40(1)(c), 44, 44A and 66 of the Customs and Excise Act; Commissioner for the South African Revenue Service $v$ Prudence Forwarding (Pty) Ltd (A406/14) [2015] ZAGPPHC 1104 par 5-6.

$50 \mathrm{~S} 1$ read with ss $39,39 \mathrm{~A}, 39 \mathrm{D}, 40(1)(c), 44,44 \mathrm{~A}$ and 66 of the Customs and Excise Act. 
African Customs Union Agreement, the term "customs duty" includes any duty that could be levied on the importer and/or MNEs, under Parts 3, 5 or 8 of Schedule 1 of the Customs and Excise Act, on goods imported into South Africa. ${ }^{51}$ However, this definition excludes any meaning and/or purposes of articles 32, 33 and 34 of the Southern African Customs Union Agreement. Nevertheless, the Customs and Excise Act does not provide any specific definitions for the terms "customs value" and "transaction value". The term "customs value" is similarly defined in the Customs Control Act and the Customs Duty Act as the value of goods for customs purposes as calculated in accordance with Chapter 7 of the Customs Duty Act.52 On the other hand, the term "transaction value" is not defined in the Customs Control Act. Nonetheless, the term "transaction value" is defined under the Customs Duty Act as the transaction value of the goods sold for export purposes to South Africa as determined in accordance with section 131 of the same Act. ${ }^{53}$

MNEs that fail to comply effectively with their retroactive transfer pricing adjustment responsibilities may risk incurring potential non-compliance penalties from SARS, especially in relation to their under-invoicing and/or under-declaration of imported goods. ${ }^{54}$ Any under-declaration of the customs value of imported goods by MNEs renders the original bill of entry invalid. 55 In this regard, the Customs and Excise Act empowers SARS to impose penalties on the offenders for any under-declaration of the customs value of their imported goods. ${ }^{56}$

Once retroactive transfer pricing adjustments are made by an MNE, a related exporting party of the MNE in question is obliged to issue an amended invoice to the related importing party of the MNE to correct the initial declared customs value of the affected imported goods. ${ }^{57}$ The MNEs are also required to notify SARS of any changes within 30 days of the retroactive transfer pricing adjustment of the customs value of the imported goods. If an MNE has paid higher duties, SARS is obliged to refund to the affected MNE the excess amount in respect of such duties. This is done after vouchers of correction relating to retroactive transfer pricing adjustments are effected by the MNEs in question. ${ }^{58} \mathrm{~A}$ voucher of correction is usually required to update the customs value of an MNE's imported goods

S 1(3) read with ss 39, 39A, 39D, 40(1)(c), 44, 44A and 66 of the Customs and Excise Act.

$\mathrm{S} 1$ of the Customs Control Act and $\mathrm{s} 1$ of the Customs Duty Act.

S 1 read with ss 131-140 of the Customs Duty Act.

54 Bakker and Obuoforibo Transfer Pricing 41-450; Dos Reis and Sarmento 2012 ISEG Paper 8-26; Antràs and Yeaple "Multinational Firms and the Structure of International Trade" 2014 Handbook of International Economics 55 56-130; Charlet and Holmes "Determining the Place of Taxation of Transactions Under VAT/GST: Can Transfer Pricing Principles Help?" 2010 International Vat Monitor 431 432-438.

55 Ss 81 and 84 read with ss 44, 44A, 78-80, 83, 91-94 of the Customs and Excise Act; see related discussion by Mendoza and Ko "Preliminary Insights From the Philippine Bureau of Customs Imports Database" 2015 World Customs Journal 83 84-88.

56 Ss 81 and 84 read with ss 44, 44A, 78-80, 83 and 91-94 of the Customs and Excise Act; Commissioner of the South African Revenue Service $v$ Formalito (Pty) [2006] 4 All SA 16 (SCA) par 1-12; Bulana "Transfer Pricing and Customs Valuation: Key Differences and Mitigation of Potential Risks" 2015 MPRA Paper 1 2-17.

57 Ss 40 and 41 of the Customs and Excise Act.

58 S 76 of the Customs and Excise Act; Bakker and Obuoforibo Transfer Pricing 41-450; Dos Reis and Sarmento 2012 ISEG Paper 8-26. 
since the bill of entry passed before the retroactive transfer pricing adjustments will be non-compliant with the provisions of the Customs and Excise Act. ${ }^{59}$

\section{The complexity of customs valuation methods negatively affects retroactive transfer pricing adjustments of imported goods}

Customs valuation methods are key to the accurate and effective enforcement of retroactive transfer pricing adjustments of imported goods in any country. Various complex customs valuation methods such as transaction value of identical goods, transaction value of similar goods, the deductive value method, the computed value method and the fallback option can be employed in respect of retroactive transfer pricing adjustments of imported goods by MNEs. ${ }^{60}$ The determination of the actual customs value of imported goods is crucially important for the realisation and imposition of the customs duty liability on MNEs for imported goods, especially the ad valorem duty. ${ }^{61}$ Furthermore, tariff classification and preferential origin are key to the establishment and imposition of customs duty liability on MNEs in respect of imported goods in South Africa and other countries. Valuation, classification and origin of goods are some of the complex factors that are very difficult to determine in respect of international trade activities between MNEs. In this regard, it is generally accepted that the transaction value method is the primary customs valuation method employed in respect of retroactive transfer pricing adjustments of imported goods by MNEs in different countries and/or jurisdictions. ${ }^{62}$

Article 8 of the WTO Agreement empowers customs authorities and/or MNEs to adjust the actual price paid or payable for imported goods in cases where certain specific elements that are considered to be part of the customs value are incurred by the buyer, yet were not included in the price actually paid or payable for the imported goods. In addition, article 8 of the WTO Agreement provides for the inclusion of certain considerations in the transaction value that may pass from the buyer to the seller in the form of specified goods or services other than in the form of money. ${ }^{63}$ Nonetheless, it is difficult to establish whether the elements stipulated in article 8 of the WTO Agreement should be strictly included in the customs value of imported goods. The determination of the actual transaction value is a complex process that requires consultation with the importer or MNEs in order to obtain all relevant information. The consultation process is also very expensive, especially the determination and approval of some elements such as royalties. Notably, there are two main factors that affect the

59 Ss 39 and 40 of the Customs and Excise Act; see related discussion by Bakker and Obuoforibo Transfer Pricing 41-450; Dos Reis and Sarmento 2012 ISEG Paper 8-26.

60 World Customs Organisation 2018 WCO Guide 10-13; see articles 2, 3, 5, 6 and 7 of the World Trade Organisation (WTO) Agreement on Implementation of Article VII of the General Agreement on Tariffs and Trade 1994 (WTO Agreement).

61 World Customs Organisation 2018 WCO Guide 6-7; see articles 1 and 8 of the WTO Agreement.

62 Ibid.

63 Ibid. 
determination of the transaction value for imported goods by MNEs. First, the actual price paid or payable for the goods when sold for export to the country of importation by MNEs. ${ }^{64}$ Secondly, a series of all cost elements (that were not included in the initial invoice, yet must be added to the price of the goods in question in terms of article 1 of the WTO Agreement,) are also considered when determining the transaction value. ${ }^{65}$ Furthermore, article 1 of the WTO Agreement also outlines certain conditions and restrictions that may affect the validity of the actual price paid or payable in respect of imported goods by MNEs.

The transaction value method for identical goods, which is provided under article 2,66 and the transaction value method for similar goods, which is provided under article $3,{ }^{67}$ requires comparable consignments to be established in order to determine any previous transaction value that was accepted by the customs department in question. The WTO Agreement provides a criterion for distinguishing identical goods from similar goods, which includes the consideration of factors such as time of importation and the commercial level of consignment for affected imported goods.

The deductive value method is generally based on the price at which the imported goods are sold on the domestic market. ${ }^{68}$ In this regard, one must establish a unit price from which costs pertaining to post-importation activities such as import transportation, storage costs and general expenses are deducted. 69 Therefore, the customs value for imported goods is determined after such deductions are made. ${ }^{70}$

The computed value method is based on a price derived from various elements that relate to manufactured goods. Such elements include the cost of relevant materials, manufacturing costs, general expenses and transport costs. ${ }^{71}$ The computed value method is expensive and is rarely used because it requires financial data that may be confidential to the manufacturer. It also involves information that the manufacturer may not be willing to release to the importer and/or the customs department of the importing country. ${ }^{72}$

The fallback option is not a specified customs valuation method, but it provides a possible means of establishing the customs value of imported goods, especially where other traditional customs valuation methods cannot be applied. ${ }^{73}$ The fallback option enumerates approaches whose value is sometimes not based on minimum customs value or where customs value is

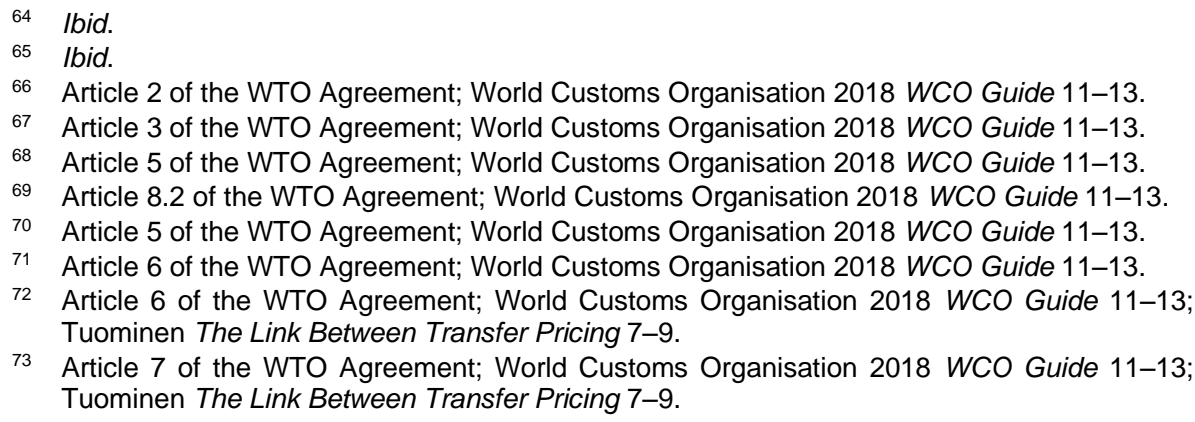

73 Article 7 of the WTO Agreement; World Customs Organisation 2018 WCO Guide 11-13; Tuominen The Link Between Transfer Pricing 7-9. 
arbitrary and/or fictitious value that is expressly prohibited by the WTO Agreement. ${ }^{74}$

No specific customs valuation methods are provided to determine the customs value of imported goods under the Customs and Excise Act in South Africa. ${ }^{75}$ However, it appears that South Africa relies on the transaction value method to determine the actual value of imported goods by MNEs. ${ }^{76}$ Therefore, it is important to note that the transaction value method provides that the value of goods imported into South Africa is determined by the price paid or payable for such goods when they are sold for export into South Africa. ${ }^{77}$ This suggests that the transaction value method is employed to determine the actual value of imported goods after retroactive transfer pricing adjustments are made by MNEs in South Africa. Nonetheless, it is very difficult to determine whether the prior relationship within and/or between MNEs influences the price payable for the affected imported goods in South Africa. SARS has to look outside the confines of the transaction value method and its rigid application to determine the actual price of imported goods after retroactive transfer pricing adjustments are effected by MNEs. ${ }^{78}$ Furthermore, alternative customs valuation methods such as the deductive value method, computed value method and the fallback option are complex and difficult for MNEs and SARS to use to determine the customs value of imported goods in respect of retroactive transfer pricing adjustments in South Africa.

The prior relationship that exists between MNEs and their subsidiary companies makes it difficult for SARS to use the transaction value method effectively to determine the actual customs value of imported goods by such MNEs after their retroactive transfer pricing adjustments in respect thereof. In this regard, the authors submit that the transaction value method should be used together with other customs valuation methods so as effectively to obtain the actual customs value of imported goods after the retroactive transfer pricing adjustments are made by MNEs. In addition, SARS should determine the price of the imported goods sold within the MNEs and contrast it with the price of identical goods sold between independent parties in order

74 Ibid.

75 Ss 65-67, 69, 71-76 and 76A-76C of the Customs and Excise Act. For related discussion, see Massimo "Customs Value and Transfer Pricing: WCO and ICC Solutions to Be Adopted by Customs Authorities" 2020 Global Trade and Customs Journal 273 274-287; Geremew Assessment of Under Invoicing Valuation System 42-100; Lushi and Gashi "Potential Risks to Avoidance of Customs Duties: Research in Kosovo" 2016 European Journal of Sustainable Development 67 68-74.

76 Fyfe Transfer Pricing and Customs Valuation Rules 20-36; see related discussion by Rajkarnikar "Implementation of the WTO Customs Valuation Agreement in Nepal: An ExAnte Impact Assessment" 2006 Asia-Pacific Research and Training Network on Trade (Working Paper Series 1806) 6-33.

77 Ss 65-67, 69, 71-76 and 76A-76C of the Customs and Excise Act; see related discussion in Levi Strauss SA (Pty) Ltd $v$ Commissioner for the South African Revenue Service (20923/2015) [2017] ZAGPPHC 990 (2 May 2017); Trend Finance (Pty) Ltd v Commissioner for the South African Revenue Service (2006) 2 BCLR 304 (C) par 7-100; Lux et al 2012 Global Trade and Customs Journal 122-142.

78 Marsilla 2011 World Customs Journal 74-84; Bakker and Obuoforibo Transfer Pricing 41-450; Dos Reis and Sarmento 2012 ISEG Paper 8-26. 
to examine whether the prior relationship between MNEs and their subsidiary companies influenced the actual customs value of such goods. ${ }^{79}$

Import transactions between two separate entities of an MNE, where one is in South Africa and another is based in a foreign country, are regarded as related party transactions. ${ }^{80}$ In this regard, note that the customs valuation of transactions between related parties of MNEs is extremely challenging for SARS. ${ }^{81}$ Accordingly, SARS should carefully scrutinise transactions between MNEs and their subsidiary companies to curb the possible abuse of retroactive transfer pricing adjustments for imported goods by MNEs in South Africa. ${ }^{82}$ Put differently, transactions between MNEs and their related parties should be carefully examined by SARS to detect and curb any possible abuse of retroactive transfer pricing adjustments of imported goods through the manipulation of prior relationships between MNEs and their related parties. ${ }^{83}$ Furthermore, if SARS discovers that the relationship between MNEs and their subsidiary companies influenced the price paid or payable for imported goods by such MNEs after retroactive transfer pricing adjustments, SARS may impose penalties on the offenders for underdeclaration and falsification of the customs value of such goods. ${ }^{84}$

In cases of related party transactions, SARS requires MNEs to complete a customs valuation questionnaire in order to determine whether the customs valuation method used to determine the customs value at the time of importation was correct and/or effectively applied by the relevant MNEs. If a wrong customs valuation method was used to determine the customs value of the imported goods, SARS must request the relevant MNE to adopt the correct customs valuation method and make retroactive transfer pricing adjustments to correct the customs value of the affected imported goods. ${ }^{85}$

79 Ruggie "Multinationals as Global Institution: Power, Authority and Relative Autonomy" 2018 Regulation \& Governance 317 319-333; Allan The OECD Transfer Pricing Guidelines 4-83; O'Shea and Rosenow A Handbook on the WTO Customs Valuation Agreement (2010) 42-177.

80 See article 15 of the WTO Agreement; see related discussion by Ping 2007 Global Trade \& Customs Journal 118-128.

81 O'Shea and Rosenow A Handbook on the WTO Customs 42-177; Borkowski "Transfer Pricing Documentation and Penalties: How Much Is Enough?" 2003 International Tax Journal 1 3-31.

82 Wolfgang and Konrad Fundamentals of International Transfer Pricing in Law and Economics (2012) 91-254; Miesel, Higinbotham and Yi "International Transfer Pricing: Practical Solutions for Intercompany Pricing" 200228 International Tax Journal 1 3-22; Cooper et al Transfer Pricing and Developing Economies 2-129; Ping 2007 Global Trade \& Customs Journal 118-128; Ratombo and Blumenthal 2017 Southern African Accounting Association Biennial International Conference Proceedings 751-764.

83 Ratombo and Blumenthal 2017 Southern African Accounting Association Biennial International Conference Proceedings 751-764; De Pagter and Van Raan The Valuation of Goods for Customs Purposes (1981) 33-53.

84 S 84 of the Customs and Excise Act; also see ss 875-882 of the Customs Control Act and see ss 211-219 of the Customs Duty Act; Trend Finance (Pty) Ltd $v$ Commissioner for the South African Revenue Service supra par 19-100; Sasol Oil Proprietary Limited v Commissioner for the South African Revenue Service (923/2017 [2019] 1 All SA 106 (SCA) par 8-145; for further discussion, see Mashiri and Sebele-Mpofu "Illicit Trade, Economic Growth and the Role of Customs: A Literature Review" 20159 World Customs Journal 38 40-50,.

85 Harmse and Van der Zwan 2016 De Jure 290-306; Lushi and Gashi 2016 European Journal of Sustainable Development 68-74. 
In this regard, SARS should determine the customs valuation method supposed to have been used at the time of importation and in some instances, a penalty for under-declaration and falsification of the customs value of the imported goods can be levied against the relevant MNE. ${ }^{86}$

The selection of the most suitable customs valuation method to determine the transaction value of imported goods between MNEs and the effective enforcement of retroactive transfer pricing adjustments in respect thereof is still very problematic for SARS. ${ }^{87}$ For instance, if SARS establishes that the relationship between an MNE and its subsidiary companies influenced the price paid or payable for the imported goods by such MNE, an alternative customs valuation method must be adopted to determine the actual price of the imported goods in question since the transaction value method will not be applicable in this regard. ${ }^{88}$ The use of alternative customs valuation methods is complex and very difficult to enforce for SARS. Alternative customs valuation methods - for example, the transaction value for similar goods method - requires an investigation into what the price of the goods being valued would be if the transaction were effected between independent parties. ${ }^{89}$ Moreover, the transaction value for similar goods method requires financial data from independent parties, which is at times difficult for SARS to get since most companies are reluctant to disclose their financial data. This is worsened by the fact that there is no express statutory obligation on MNEs to disclose their financial data to SARS for customs valuation purposes under the Customs and Excise Act, the Customs Duty Act and the Customs Control Act. In this regard, the adoption and use of alternative customs valuation methods for retroactive transfer pricing adjustments of imported goods is a difficult task for both SARS and MNEs.

The onus is normally placed on the importer (affected MNE) to prove that the price paid or payable is the same as the price of similar or identical imported goods sold under the same conditions as the goods being valued between unrelated parties. ${ }^{90}$ This is a time-consuming and costly exercise for both MNEs and SARS as the services of a customs valuation specialist are needed to evaluate all retroactive transfer pricing adjustments of imported goods by MNEs. ${ }^{91}$ In addition, the process of comparing the prices of identical goods can be hindered by the reluctance of companies trading with the same or similar products to those being valued to disclose their

86 Harmse and Van der Zwan 2016 De Jure 290-306; Lushi and Gashi 2016 European Journal of Sustainable Development 68-74; Eden in Rugman Oxford Handbook of International Business 591-617.

87 Subban "Customs and Transfer Pricing: What Is SARS up to?" 201313 Without Prejudice 44 44-45; Ainsworth 2007 Rutgers Computer \& Tech. LJ 4-167; Lord Transfer Pricing in South African Income Tax Law (unpublished LLM dissertation, University of Cape Town) 2014 8-65; Erturk "Intangible Assets and Customs Valuation" 201812 World Customs Journal 69 70-78.

88 Fritz An Appraisal of Selected Tax-Enforcement Powers 57-303; De Wulf and Sokol Customs Modernization Handbook (2005) 159-300; Erturk 2018 World Customs Journal 70-78.

89 De Pagter and Van Raan The Valuation of Goods 33-53.

90 Wolfgang and Konrad Fundamentals of International Transfer Pricing 91-254.

91 McClure "Coordinating Transfer Pricing Reports for Income Tax and Customs: Can an OECD Report Be Tailored to Satisfy Both Section 482 and Customs Purposes?" 200860 Tax Executive 435 436-444. 
manufacturing and pricing processes. Thus, the determination of the prices of comparable transactions is a complex and difficult task for both SARS and MNEs. ${ }^{92}$

\section{The complexity of transfer pricing policies and transfer pricing methods negatively affects retroactive transfer pricing adjustments of imported goods}

The OECD transfer pricing guidelines stipulate about five transfer pricing methods that may be employed by MNEs and customs authorities to interpret and enforce the ALP - namely, the comparable uncontrolled price method; resale price method; cost-plus method; transactional net-margin method and the transactional profit-split method.93 The comparable uncontrolled price method, resale price method and cost-plus method are generally referred to as the "traditional transactional methods". ${ }^{94}$ Likewise, the transactional net-margin method and the transactional profit-split method are also known as the "transactional profit methods". ${ }^{95}$

The comparable uncontrolled price method (CUP method) compares the price charged for goods or services (including the provision of finance and intangibles) transferred in a controlled transaction to the price charged for goods or services transferred in a comparable uncontrolled transaction in comparable circumstances. ${ }^{96}$ The CUP method may be used to determine the ALP for royalties in respect of intangible assets. The CUP method applies to both internal and external comparable transactions and where the transaction prices for imported goods or services by MNEs differ, it is generally regarded as an indication that the conditions in the controlled transaction were not agreed by the relevant parties at arm's length. ${ }^{97}$ In this regard, it is crucial to note that even minor comparability differences may have a material impact on the condition being examined by the relevant customs authorities. The required standard of comparability for the CUP method is higher relative to the other transfer pricing methods stated above..$^{98}$ The main advantage of the CUP method is that the actual price of imported goods or services for MNEs in an affected transaction is compared to other related transactions to achieve an objective and independent analysis. Notably, an uncontrolled transaction is generally considered comparable to a controlled transaction if there are no differences in the transactions being compared that would materially affect the price of the

92 Melnychenko, Pugachevska and Kasianok "Tax Control of Transfer Pricing" 2014 Investment Management and Financial Innovations 40 42-49.

93 UN "Practical Manual on Transfer Pricing for Developing Countries" 2013 United Nations Practical Manual on Transfer Pricing 1 196-257; Bakker and Obuoforibo Transfer Pricing 41-450.

94 UN 2013 United Nations Practical Manual on Transfer Pricing 196-257; World Customs Organisation 2018 WCO Guide 32-45.

95 Ibid.

96 Ibid.

97 Ibid

98 Ibid. 
imported goods or services. ${ }^{99}$ An uncontrolled transaction is also generally considered comparable to a controlled transaction if accurate adjustments can be performed objectively to account for material differences between the controlled and uncontrolled transactions. ${ }^{100}$ Nonetheless, the challenges associated with the comparability differences and related analysis could suggest that the CUP method is less likely to be the most appropriate method for more complex transactions, especially the retroactive transfer pricing adjustments involving imported non-commoditised goods, services or intangibles in South Africa. ${ }^{101}$

The resale price method entails that goods or services that are subject to a controlled transaction are resold to an independent party to obtain a resale price and that the price is then reduced by an appropriate gross profit margin (resale price margin) in order to determine an arm's length price. ${ }^{102}$ The appropriate resale price margin is determined by reference to the relevant gross margin and other comparable uncontrolled transactions. Proper accounting measures must be in place and consistently applied by customs authorities such as SARS for the effective application of the resale price method. The resale price margin earned by the reseller of the imported goods or services should be carefully examined by the customs authorities and/or SARS in South Africa. It appears that the resale price method merely requires the selection of a tested party. A tested party is a party that purchases the goods or services in the controlled transaction for reselling. The resale price margin represents the margin that a reseller of the relevant goods or services seeks to make in order to cover its operating expenses, taking into account all the relevant factors such as the expenses incurred and the risks involved. ${ }^{103}$ The appropriate resale price margin may be determined by reference to gross profit margins earned in internal comparable uncontrolled transactions or by reference to the gross profit margins earned by independent parties in external comparable uncontrolled transactions. ${ }^{104}$ It is important to note that minor differences in the comparability and characteristics of the affected goods may negatively affect the condition being examined in terms of the resale price method. The resale price method provides that parties with comparable functional profiles should be compensated similarly. One of the main advantages of the resale price method is that the relevant condition is examined at the gross margin level by customs authorities such as SARS and there is minimal scope for variables that are unrelated to the transfer price under the controlled transaction to affect the independent price. ${ }^{105}$ Nonetheless, the resale price method requires the selection of a tested party. Furthermore, an arm's length resale margin for one party may give rise to a negative result for the other party to a controlled transaction that was not concluded by the relevant MNEs at arm's length. ${ }^{106}$ 
The cost-plus method entails that the costs incurred by the supplier of the goods or services that are the object of the controlled transaction should be marked up appropriately in order to determine an arm's length price. ${ }^{107}$ Accordingly, the appropriate cost-plus mark-up is determined by reference to the gross margins earned in comparable uncontrolled transactions. Furthermore, proper accounting measures must be in place and consistently applied by the customs authorities to establish an appropriate composition of the relevant cost base for the relevant goods or services of the MNEs. ${ }^{108}$ This is key to the effective application of the cost-plus method. The cost-plus mark-up represents the margin that a supplier of the relevant goods or services seeks to make in order to recover all its incurred operating expenses. The appropriate cost-plus margin may be determined by reference to the gross profit margins earned in internal uncontrolled comparable transactions or by reference to the margins earned by independent parties in external comparable uncontrolled transactions of the affected MNEs. ${ }^{109}$ Nevertheless, it is very difficult for SARS to establish, interpret and apply comparable cost-plus margins, whether to test compliance of the relevant MNEs with the arm's length principle (especially in respect of their retroactive transfer pricing adjustments) or as a reference point for setting the prices in the controlled transactions.

The transactional net-margin method (TNMM) entails that an appropriate financial indicator based on the net profit that a tested party realises in controlled transactions should be compared with that realised in comparable uncontrolled transactions to establish an arm's length price for the MNE's imported goods or services. ${ }^{110}$ The appropriate financial indicator will vary, depending on the facts, circumstances and the selection of the tested party. The appropriate financial indicator is determined by reference to the net profit (operating margin) earned in comparable uncontrolled transactions. Minor differences in the characteristics of the goods or services of the affected MNEs may not materially affect the condition being examined or the net profit margin under the TNMM. However, minor differences regarding the industry, goods or services of the affected MNE are more likely to have a material impact on the price or gross margin as opposed to the net profit margin of the goods or services of that MNE. Parties with comparable functional profiles will be compensated similarly under the TNMM.

The transactional profit-split method entails that the relevant profits or losses arising from controlled transactions should be split between the associated companies of the MNEs that are party to those transactions on an economically valid basis. ${ }^{111}$ This economically valid basis should be supported by market data. Nevertheless, such market data is not always easily accessible to SARS and/or other customs authorities. Consequently, different approaches may be employed to determine the appropriate arm's length split of profits between the relevant parties. For instance, under the comparable profit-split approach, relevant profits are split after comparing 
the split of profits observed between independent companies in comparable transactions. ${ }^{112}$ Using the contribution analysis approach, relevant profits or losses from controlled transactions are allocated between the associated parties on the basis of their relative contributions. ${ }^{113}$ Residual analysis approach allocates profits to non-unique activities of the associated parties and then splits the residual profit or loss on an economically valid basis between the relevant parties. The transactional profit-split method is used in controlled transactions where each party to the transaction makes unique and valuable contributions that cannot reliably be measured by reference to comparable uncontrolled transactions. ${ }^{114}$ As a result, the relevant parties to the transactions share significant economic risks associated with those transactions. This transactional profit-split method is very difficult for SARS to comply with.

Flawed transfer pricing policies and onerous documentation requirements for retroactive transfer pricing adjustments of imported goods by MNEs in South Africa represent a further challenge. For instance, SARS uses a difficult transfer pricing and valuation questionnaire to investigate and determine whether the relationship between MNEs and their subsidiary companies influenced the price of their imported goods. ${ }^{115}$ The transfer pricing and valuation questionnaire requires the importers (MNEs) to provide information on how the value of their imported goods was determined. Moreover, SARS may require MNEs to provide supporting documents such as invoices and sale agreements to verify the correctness of each completed transfer pricing and valuation questionnaire. ${ }^{116}$ In this regard, when MNEs file their annual corporate income tax returns, they are required to indicate if they have performed any retroactive transfer pricing adjustments on their imported goods in the year. This is required by SARS to combat any possible misuse of retroactive transfer pricing adjustments of imported goods by unscrupulous MNEs in South Africa. ${ }^{117}$

Notwithstanding that it is not compulsory for MNEs to prepare and submit their transfer pricing policies, SARS may request such policies from MNEs. ${ }^{118}$ SARS recommends that all MNEs should prepare and submit their transfer pricing policies to avoid incurring penalties for non-disclosure. ${ }^{119}$ MNEs that do not provide documentary proof and transfer pricing policies to

112 Ibid.

113 lbid.

114 Ibid.

115 UN 2013 United Nations Practical Manual on Transfer Pricing 196-257; Harmse and Van der Zwan 2016 De Jure 290-306; Fyfe Transfer Pricing and Customs Valuation Rules 31-36.

116 Rule 65.01 to the Customs and Excise Act; Schippers "A Series of Sales: Determining the Customs Value under the Union Customs Code" 201813 Global Trade and Customs Journal 36 40-48.

117 Muljee South African Transfer Pricing Income Tax Legislation: Is There Still a Gap? (unpublished Master of Commerce dissertation, University of the Witwatersrand) 2017 2-85; Markham The Transfer Price of Intangibles (2005) 50-300.

118 Allan The OECD Transfer Pricing Guidelines 4-83; The South African Institute of Tax Practitioners (SAIT) Compendium of Tax Legislation (2010) 100-523; Feinschreiber Transfer Pricing Methods: An Applications Guide (2004) 5.

119 Ss 210-215 and 221-224 of the Tax Administration Act 28 of 2011; SAIT Compendium of Tax Legislation 100-523. 
substantiate that the prices of their imported goods were valued at arm's length will be penalised by SARS. ${ }^{120}$ MNEs that prepare and maintain a transfer pricing policy enable tax and customs authorities to detect and combat risks associated with the manipulation of retroactive transfer pricing adjustments of imported goods by MNEs in South Africa. ${ }^{121} \mathrm{~A}$ transfer pricing policy provides SARS with guidelines on how the retroactive transfer pricing adjustments for imported goods were effected, as well as the formulas and factors that led to such adjustments being performed by the relevant MNEs. ${ }^{122}$ Transfer pricing documentation must be drafted so that it can be used to prove compliance by the MNEs and prove that the price paid or payable for imported goods complies with the transactional value method. ${ }^{123}$ However, maintaining a transfer pricing policy is time-consuming and costly for MNEs and is difficult to comply with effectively. ${ }^{124}$

On its own, a transfer pricing policy cannot be accepted as proof that the price paid or payable for imported goods was at arm's length and/or not influenced by the relationship between an MNE and its subsidiary companies. ${ }^{125}$ Accordingly, additional information and documents such as pricing agreements must be submitted by MNEs to SARS for it to determine whether the prior relationship between an MNE and its subsidiary companies influenced the price of imported goods during retroactive transfer pricing adjustments. ${ }^{126}$ In this regard, it must be noted that the onus is on the MNEs to indicate such relevant additional information in the transfer pricing policy and submit it to SARS. ${ }^{127}$

There is no express statutory provision regarding the establishment and enforcement of transfer pricing policies under the Customs and Excise Act, the Customs Control Act and the Customs Duty Act. Moreover, there are no statutory requirements for MNEs to adopt and maintain a transfer pricing policy in South Africa. ${ }^{128}$ This suggests that MNEs are not statutorily obliged

120 Cooper et al Transfer Pricing and Developing Economies 2-129; Ping 2007 Global Trade \& Customs Journal 118-128; Muljee Transfer Pricing Income Tax Legislation 2-85; Unilever Kenya Ltd $v$ Commissioner of Income Tax Appeal 753 of 2003 par 11.

121 Cooper et al Transfer Pricing and Developing Economies 2-129; Ping 2007 Global Trade \& Customs Journal 118-128.

122 Ping 2007 Global Trade \& Customs Journal 118-128.

123 Allan The OECD Transfer Pricing Guidelines 4-83; Muljee Transfer Pricing Income Tax Legislation 2-85.

124 Lord Transfer Pricing in South African Income Tax Law 8-65; Allan The OECD Transfer Pricing Guidelines 4-83; King Transfer Pricing and Corporate Taxation: Problems, Practical Implications and Proposed Solutions (2009) 54-150.

125 Ping 2007 Global Trade \& Customs Journal 118-128; Eden in Rugman Oxford Handbook of International Business 591-617.

126 Ainsworth 2007 Rutgers Computer \& Tech. LJ 4-167; David, Toro and Caballero "An Opportunity to Support US Customs Valuations" 201223 International Tax Review 46 47-49; Bakker and Levey Transfer Pricing and Intra-Group Financing: The Entangled World of Financial Markets and Transfer Pricing (2012) 121-450; Wolfgang and Konrad Fundamentals of International Transfer Pricing 91-254.

127 Ainsworth 2007 Rutgers Computer \& Tech. LJ 4-167; David et al 2012 International Tax Review 47-49; Jovanovich Customs Valuation and Transfer Pricing: Is it Possible to Harmonise Customs and Tax Rules? (2002) 20-120.

128 See SARS Practice Note 7 par 10.2.1; Mberi Addressing Challenges Facing SARS Relating to the Application of Transfer Pricing in Business Restructurings (Master of Commerce dissertation, North-West University) 2012 7-60; Mazansky “Transfer Pricing Documentation 
to adopt and maintain transfer pricing policies and related documents under the Customs and Excise Act, the Customs Control Act and the Customs Duty Act. ${ }^{129}$ This statutory gap could enable MNEs to ignore SARS's recommendation that they adopt and maintain adequate transfer pricing policies and related documentation. ${ }^{130}$

The transfer pricing documentation and transfer policies differ from company to company, making it difficult for SARS to understand each of them. ${ }^{131}$ For example, MNEs often include what they deem to be pertinent and important information in their transfer pricing documentation and transfer policies. This approach is biased and inaccurate. ${ }^{132}$

\section{The disruptive effect of the coronavirus (Covid- 19) pandemic on transfer pricing activities of MNES}

The Covid-19 pandemic has affected the global economy and various business activities, including transfer pricing policies and retroactive transfer pricing adjustments of imported goods by MNEs in South Africa and many other countries. The disruptive impact of the Covid-19 pandemic has affected governments and customs authorities of various countries around the world, including South Africa. ${ }^{133}$ The closure of borders, global lockdown and other Covid-19 pandemic restrictions imposed by governments of many countries globally have negatively affected the collection of additional revenue by customs authorities. Consequently, transfer pricing policies and retroactive transfer pricing adjustments of imported goods by MNEs need to be reconsidered by SARS in light of the devastating effects that the Covid-19 pandemic has had on the South African economy to date; ${ }^{134}$ very few MNEs have post-Covid-19 pandemic recovery plans in place to deal with and/or ameliorate the negative effects of Covid-19 on retroactive transfer pricing adjustments of imported goods and related activities by MNEs in South Africa. ${ }^{135}$ One potential challenge faced by MNEs concerns permanent establishments and their effect on tax liabilities for MNEs, especially during

Requirements Clarified" 2005 Tax Breaks 7-8; Alecu and Vasilescu "What Will Transfer Pricing Look Like After Covid-19?" 2020 Tax Magazine 115 116-118.

129 Allan The OECD Transfer Pricing Guidelines 4-83; Schnorberger, Gerdes, Van Herksen "Transfer Pricing Documentation: The EU Code of Conduct Compared with Member State Rules (Part 3)" 200634 Intertax 514 515-520.

130 Allan The OECD Transfer Pricing Guidelines 70-83; Meditor Capital Management Ltd v Feighan supra; Shrivastava, Sharma, Chauhan and Meitram Income Tax Act 2009 (2009) 689-900.

131 Moyo A Comparative Analysis of the Legislative Requirements of Transfer Pricing Documentation (unpublished Master of Commerce dissertation, University of Johannesburg) 2015 6-47; Miesel et al 2002 International Tax Journal 1 3-22.

132 Drtina and Reimers "Global Transfer Pricing: A Practical Guide for Managers" 200974 SAM Advanced Management Journal 4 6-12.

133 Alecu and Vasilescu 2020 Tax Magazine 115 116-118.

134 Alecu and Vasilescu 2020 Tax Magazine 116-118; Löffie "Divisionalization and Domestic Transfer Pricing for Tax Considerations in the Multinational Enterprise" 2019 Management Accounting Research $12-9$.

135 Collier, Pirlot and Vella "COVID-19 and Fiscal Policies: Tax Policy and the COVID-19 Crisis" 2020 Intertax 794 796-804; Löffie 2019 Management Accounting Research 2-9. 
global lockdown, where, by virtue of the closed borders some MNEs were locked down in other countries where they do not normally conduct their businesses. A permanent establishment generally refers to a fixed place of business that gives rise to income or value-added tax liability on the part of MNEs in a country or a particular jurisdiction. ${ }^{136}$ This created a huge challenge for MNEs that extended their stay in certain countries or jurisdictions owing to closed borders and other Covid-19 restrictions. It is unclear whether such MNEs should be treated as having satisfied permanent-establishment requirements and be liable for value-added tax. All these challenges make it difficult for MNEs to comply effectively with the retroactive transfer pricing adjustments for imported goods in South Africa. In this light, SARS should reconsider its rules and regulations for retroactive transfer pricing adjustments for imported goods by MNEs and address the negative effects of the Covid-19 pandemic on the activities of MNEs in South Africa.

The Covid-19 pandemic has also led to increased transfer pricing documentation and imposed a higher burden of proof on MNEs regarding their retroactive transfer pricing adjustments and compliance with ALP requirements for imported goods. ${ }^{137}$

\section{CONCLUDING REMARKS}

The article has unpacked various regulatory challenges affecting the retroactive transfer pricing adjustments and customs valuation processes of imported goods under the Customs and Excise Act, the Customs Duty Act and the Customs Control Act. ${ }^{138}$ Accordingly, an overview analysis of selected regulatory and related challenges affecting the retroactive transfer pricing adjustments and the actual valuation processes of imported goods by MNEs and the SARS were discussed. For instance, it was noted that most MNEs struggle to pass a voucher of correction effectively on retroactive transfer pricing adjustments for imported goods and to comply timeously with all the relevant customs regulations of SARS. This reality is worsened by the complexity of the customs valuation methods, which negatively affects the retroactive transfer pricing adjustments of imported goods by MNEs in South Africa. Furthermore, the complexity of transfer pricing policies and transfer pricing methods also negatively affects retroactive transfer pricing adjustments of imported goods by MNEs in South Africa. Covid-19 challenges have also contributed to negative compliance with retroactive transfer pricing adjustments and valuation measures by MNEs in South Africa.

In light of the above, the authors submit that SARS should reconsider its rules and regulations for retroactive transfer pricing adjustments for imported

36 Löffie 2019 Management Accounting Research 2-9; Collier et al 2020 Intertax 796-804.

137 Visser "Multinationals: Transfer Pricing Policies To Be Scrutinised Post-Covid" (2 December 2020) https://www.moneyweb.co.za/news/south-africa/multinationals-should-expectintense-scrutiny-on-transfer-pricing-policies-post-covid/ (accessed 2020-12-02).

138 Tanzi "Globalisation, Technological Developments, and the Work of Fiscal Termites" 2000 IMF Working Paper WP/00/181 1 3-19; Blouin "Taxation of Multinational Corporations" 20126 Foundations and Trends in Accounting 13-55. 
goods by MNEs so as to combat all possible negative effects of the Covid-19 pandemic on the activities of MNEs in South Africa. Owing to the challenges associated with the Covid-19 pandemic, SARS should streamline its transfer pricing documentation requirements and evidentiary burden on MNEs in respect of their retroactive transfer pricing adjustments to improve their compliance with ALP requirements for imported goods in South Africa. Moreover, policy makers should consider enacting adequate statutory provisions to deal with the establishment and enforcement of transfer pricing policies in the Customs and Excise Act, the Customs Control Act and the Customs Duty Act. Moreover, policy makers should amend the Customs and Excise Act, the Customs Control Act and the Customs Duty Act to introduce robust and mandatory statutory requirements for MNEs to adopt and maintain transfer pricing policies in South Africa. The aforesaid legislation should be further amended to enact provisions that specifically deal with customs valuation methods and transfer pricing methods to enhance the customs valuation and retroactive transfer pricing adjustments of imported goods by MNEs in South Africa. ${ }^{139}$

139 Kamdar "Acceptable Methods for Determining an Arm's Length Price for Transfer Pricing" 2018 Tax Professional 18 19-27; Melnychenko et al 2014 Investment Management and Financial Innovations 42-49; Riedel and Zinn "The Increasing Importance of Transfer Pricing Regulations: A Worldwide Overview" 201442 Intertax 352 355-404. 